\title{
Genetic relationships between three indigenous cattle breeds in Mozambique
}

\author{
A. Kotze ${ }^{1}$, M. Harun ${ }^{2}$, F. Otto ${ }^{3}$ and F.H. Van der Bank ${ }^{4 *}$ \\ ${ }^{1}$ ARC Animal Improvement Institute, P/Bag X2, Irene, 0062, South Africa; ${ }^{2}$ Veterinary Faculty, Eduardo Montlana University, \\ C.P. 257, Maputo, Mozambique; ${ }^{3}$ German Society for Technical Co-operation (GTZ), Maputo, Mozambique \\ ${ }^{4}$ Department of Zoology, Rand Afrikaans University, P.O. Box 524, Auckland Park, 2006, South Africa.
}

\begin{abstract}
This study provides the first account of genetic relationships between three indigenous cattle breeds from Mozambique. Forty-two blood group factors and six blood proteins revealed genetic variation of 84\% (Angone), 88\% (Bovine de Tete) and 90\% (Landim) at the loci studied. Average heterozygosity values ranged from 33\% for Angone and Bovine de Tete to $35 \%$ for the Landim. The genetic distance was greatest between the Landim and both the Bovine de Tete and the Angone breeds, whereas the smallest genetic distance was observed between the Bovine de Tete and the Angone. These results show the intermediate relationship of Bovine de Tete with the Angone and Landim breeds and show that the Bovine de Tete is an admixture of taurine and indicus genes.
\end{abstract}

Keywords: Cattle, blood factors, genetic variation, genetic distance.

*Author to whom correspondence should be addressed; E-mail: fhvdb@ na.rau.ac.za

\section{Introduction}

The classification of cattle types has traditionally been based on characteristic morphological features such as the hump, horns, facial and poll profile, and dewlap. Two main types were recognized, the European Bos taurus and the Asian and African B. indicus cattle. However, in Africa a variety of cattle types are found, including the humpless and humped breeds as well as short-horned, hamitic long-horned and lateral-horned Zebu breeds. The Angone, Malawi Zebu and Masai breeds have been classed as Zebu-Sanga, and are all generally recognized as Zebu breeds. The original Sanga cattle from Ethiopia, with characteristic long horns and a small to medium cervico-thoracic hump, have spread southwards to form many different breeds and types including a number of breeds indigenous to Mozambique (Alberro, 1983). These breeds are genetically distant from other B. taurus and $B$. indicus breeds (Manwell \& Baker, 1980).

The name 'Landim' is accorded to the Nguni type of cattle found in eastern Swaziland and the Zululand territory of South Africa. In Mozambique, Landim cattle are kept in suitable areas of the plains of Gaza, in the Inhambane coastal area and in Maputo Province. Small herds are also found on the northern shores of the Limpopo River near Zimbabwe where they interbreed with Mashona cattle (Alberro, 1983). These cattle can survive on marginal land, are resistant to local diseases and are well adapted to their environment (heat tolerance).

The Angone breed is found in the fertile region of Angonia, a high plateau with an average altitude of $1300 \mathrm{~m}$, located east of the Cabora Bassa Dam on the Zambezi River in the northeast corner of Tete Province, bordering Malawi. Phenotypically, this breed is clearly one of the short-horned East African Zebu breeds to which the South Malawi Zebu and the Zambia Angoni also belong (Alberro, 1983).

The Bovine de Tete breed is found in low numbers in a narrow stretch of Mozambique along the border up to the southwest in the Tete Province. It is believed that this breed or type is an admixture of the Zebu types that migrated to Mozambique through northeast Africa. The Zebu rapidly displaced the Sanga types from Ethiopia to the Zambezi River. This process of displacement is still taking place in eastern Africa (Mason, 1975)

Studies on genetic relationships between different types of cattle are effective aids to the understanding of their phylogenies as well as for the assessment of their genetic diversities. These relationships may reflect breed histories and thereby illuminate human migrations, identify breeds potentially useful in breeding programmes and aid in understanding domestication. Blood group antigens, protein polymorphisms and microsatellites have been shown to be of use for such population studies. The aim of this study was to collect information on allele frequencies at several blood group and blood protein loci in order to investigate genetic diversity of the indigenous cattle breeds of Mozambique. This study is the first to examine genetic relationships between the Landim, Bovine de Tete and Angone cattle breeds. 


\section{Material and methods}

Genetically unselected animals were sampled from the rural small-farmer sector where cattle are kept under extensive management systems. In general, animals grazed natural pastures and most of the farmers confined their animals at night. The calving season normally takes place at the beginning of the rainy season, and dipping is part of the normal management system. Samples were collected at dipping tanks from the Tete Province for Angone and Bovine de Tete breeds and from Maputo Province for the Landim breed. The sampling locations and numbers of animals examined are shown in Table 1. Whole blood samples were collected from unrelated individuals. The analysis and the phenotypic descriptions for horn shape and coat colour were noted.

Table 1 Location, number of animals and phenotype description of the three breeds studied in this trail

\begin{tabular}{|c|c|c|c|c|c|}
\hline \multirow[t]{2}{*}{ Breed } & \multirow[t]{2}{*}{ Location } & \multicolumn{2}{|c|}{ Number } & \multicolumn{2}{|c|}{ Description } \\
\hline & & Male & Female & Horns & Coat colour \\
\hline \multirow[t]{3}{*}{ Angone } & Ntengombalame & 3 & 6 & Short & $\begin{array}{l}\text { Black, dark red, black } \\
\text { with white spots }\end{array}$ \\
\hline & Jemusse & 2 & 6 & Short & $\begin{array}{l}\text { Black, brown stripes, } \\
\text { white spots \& head }\end{array}$ \\
\hline & Chivomodzi & 11 & 15 & $\begin{array}{l}\text { Short/ } \\
\text { long/thick }\end{array}$ & $\begin{array}{l}\text { Red, cream, black, } \\
\text { white spots }\end{array}$ \\
\hline \multirow[t]{3}{*}{ Bovine de Tete } & Muchamba & 2 & 6 & $\begin{array}{l}\text { Long/lateral } \\
\text { thick }\end{array}$ & $\begin{array}{l}\text { Black, white, cream } \\
\text { gray }\end{array}$ \\
\hline & Moatize & 2 & 17 & Long/short & $\begin{array}{l}\text { Black, brown, dark } \\
\text { red, dewlap, spots }\end{array}$ \\
\hline & M'padue & & 6 & Long & $\begin{array}{l}\text { Brown, red, white, } \\
\text { black, dark red, } \\
\text { reduced hump }\end{array}$ \\
\hline \multirow[t]{3}{*}{ Landim } & Chiquizela & 6 & 11 & Long/short & $\begin{array}{l}\text { Black, white, dark } \\
\text { brown, brown \& } \\
\text { white }\end{array}$ \\
\hline & Manhiça & 3 & 12 & $\begin{array}{l}\text { Long/short, } \\
\text { outward or } \\
\text { inward curlin }\end{array}$ & $\begin{array}{l}\text { Black, brown, red, } \\
\text { white, spots } \\
\text { g }\end{array}$ \\
\hline & $\begin{array}{l}\text { Maputo } \\
\text { (IPA station) }\end{array}$ & 3 & & & \\
\hline
\end{tabular}

Blood $(10 \mathrm{ml})$ was collected into sodium EDTA tubes. Red blood cells were obtained for serological typing with nine systems (A, B, FV, J, L, SU and Z) comprising 42 blood group factors. A total of 24 of these factors are known to be polymorphic in cattle. Nomenclature is in accordance with guidelines prepared by the International Society for Animal Genetics (ISAG). Standard immunological procedures involving rabbit complement mediated haemolysis were used to detect RBC allo-antigens (Stormont, 1962). The reagents were prepared by alloimmunization with suitable absorptions to render the antisera specific for a single antigenic determinant.

Gel electrophoresis on starch and polyacrylamide gel matrixes was used to analyze inherited biochemical differences in the red blood cells and plasma. Six blood protein loci comprising 22 alleles were analyzed, viz. haemoglobin $(\mathrm{Hb})$, serum albumin (Alb), transferrin (Tf), vitamin D-binding protein $(\mathrm{Gc})$, post-transferrin-1 (Ptf1), -2 (Ptf-2) and two iso-enzymes, amylase (Am) and carbonic anhydrase (Ca).

Blood group frequencies were calculated as a single factor per locus since phenogrouping was not possible. It was found that phenogroup limitations in indigenous cattle breeds are difficult or impossible to determine because of phenogroup crossovers (Kotze \& Muller, 1994). Allelic frequencies for protein and enzyme polymorphisms were determined by direct counting from phenotypes. The values of genetic distances among populations (Cavalli-Sforza \& Edwards, 1967, chord distance; Nei, 1972, 1978; Rogers, 1972), cluster analysis using the unweighted group pair method (UPGMA algorithm), average heterozygosity $(\boldsymbol{H})$, percentage of polymorphic loci $(\boldsymbol{P})$, Wright's (1978) fixation $(\boldsymbol{F})$ and contingency Chi-square values were computed using BIOSYS-1 (Swofford \& Selander, 1981). 


\section{Results and discussion}

According to Maillard et al. (1993), the $\mathrm{Hb}^{*} \mathrm{~A}$ allele is a marker for B. taurus, with frequencies always higher than $90 \%$. In $B$. indicus breeds this frequency rarely exceeds $50 \%$. The Angone and Landim breeds, with frequencies of 64 and $80 \%$ respectively (Table 2), clearly indicate the intermediate position of Bovine de Tete $(70 \%)$. The I allele, characteristic in the southern African Sanga, occurs in low frequencies in the Bovine de Tete and Landim. The Alb*F allele is a marker for taurine influence (Milliard et al., 1993). Genotype frequencies for the cattle breeds are listed in Tables 2 and 3. The Bovine de Tete again shows an intermediate frequency. It was concluded that the Bovine de Tete shows evidence of the presence of both taurine and indicus features. The $\mathrm{C}$ allele is characteristic of indicus types, therefore the Bovine de Tete breed can be regarded as a mixture.

The Tf system shows a high frequency of the B allele in Zebu breeds. Results obtained from this study differ from results obtained by Milliard et al. (1993). The taurine type showed a high frequency of the B allele, and Bovine de Tete showed an intermediate frequency at this allele. However, the F allele (characteristic for indicus breeds) was intermediate in Bovine de Tete.

Table 2 Genotype frequencies at eight protein coding loci in three cattle breeds in Mozambique $(1=$ Angone, $2=$ Bovine de Tete, 3 = Landim)

\begin{tabular}{|c|c|c|c|c|c|c|c|c|c|}
\hline \multirow[t]{2}{*}{ Locus } & \multirow[t]{2}{*}{ Breed } & \multicolumn{5}{|c|}{ Allele } & \multirow[b]{2}{*}{$\mathrm{F}$} & \multirow[b]{2}{*}{ I } & \multirow[b]{2}{*}{$\mathrm{S}$} \\
\hline & & A & B & $\mathrm{C}$ & D & E & & & \\
\hline \multirow[t]{3}{*}{$\mathrm{Hb}$} & 1 & 0.638 & 0.362 & & & & & & \\
\hline & 2 & 0.697 & 0.258 & & & & & 0.045 & \\
\hline & 3 & 0.800 & 0.114 & & & & & 0.086 & \\
\hline \multirow[t]{3}{*}{ Alb } & 1 & & & 0.069 & & & 0.448 & & 0.483 \\
\hline & 2 & & & 0.015 & & & 0.621 & & 0.364 \\
\hline & 3 & & & & & & 0.743 & & 0.257 \\
\hline \multirow[t]{3}{*}{$\mathrm{Tf}$} & 1 & 0.379 & 0.034 & & 0.086 & 0.414 & 0.086 & & \\
\hline & 2 & 0.375 & 0.047 & & 0.141 & 0.406 & 0.031 & & \\
\hline & 3 & 0.338 & 0.059 & & 0.353 & 0.250 & & & \\
\hline \multirow[t]{3}{*}{ Gc } & 1 & 0.828 & 0.172 & & & & & & \\
\hline & 2 & 0.864 & 0.136 & & & & & & \\
\hline & 3 & 0.829 & 0.171 & & & & & & \\
\hline \multirow[t]{3}{*}{ Ptf-1 } & 1 & 0.931 & 0.069 & & & & & & \\
\hline & 2 & 0.939 & 0.061 & & & & & & \\
\hline & 3 & 0.857 & 0.143 & & & & & & \\
\hline \multirow[t]{3}{*}{ Ptf-2 } & 1 & 0.241 & 0.795 & & & & & & \\
\hline & 2 & 0.485 & 0.515 & & & & & & \\
\hline & 3 & 0.514 & 0.486 & & & & & & \\
\hline \multirow[t]{3}{*}{$\mathrm{Am}$} & 1 & & 0.828 & 0.172 & & & & & \\
\hline & 2 & & 0.909 & 0.091 & & & & & \\
\hline & 3 & & 0.829 & 0.171 & & & & & \\
\hline \multirow[t]{3}{*}{$\mathrm{Ca}$} & 1 & 0.017 & 0.983 & & & & & & \\
\hline & 2 & 0.030 & 0.970 & & & & & & \\
\hline & 3 & 0.043 & 0.957 & & & & & & \\
\hline
\end{tabular}


(c) South African Society of Animal Science

Table 3 Genotype frequencies for 42 blood group factors in three cattle breeds in Mozambique $(1=$ Angone, $2=$ Bovine de Tete, 3 = Landim)

\begin{tabular}{|c|c|c|c|c|c|c|c|}
\hline \multirow[t]{2}{*}{ Locus } & \multirow[t]{2}{*}{ Breed } & \multicolumn{2}{|c|}{ Allele } & \multirow[t]{2}{*}{ Locus } & \multirow[t]{2}{*}{ Breed } & \multicolumn{2}{|c|}{ Allele } \\
\hline & & A & B & & & A & $\mathrm{B}$ \\
\hline \multirow[t]{3}{*}{ A2 } & 1 & 0.828 & 0.172 & $\mathrm{H}$ & 1 & 0.690 & 0.310 \\
\hline & 2 & 0.545 & 0.455 & & 2 & 0.455 & 0.545 \\
\hline & 3 & 0.829 & 0.171 & & 3 & 0.543 & 0.457 \\
\hline \multirow[t]{3}{*}{$Z^{\prime}$} & 1 & 0.241 & 0.759 & $\mathrm{C} 2$ & 1 & 0.759 & 0.241 \\
\hline & 2 & 0.091 & 0.909 & & 2 & 0.667 & 0.333 \\
\hline & 3 & 0.200 & 0.800 & & 3 & 0.857 & 0.143 \\
\hline \multirow[t]{3}{*}{ B-2 } & 1 & 0.448 & 0.552 & $\mathrm{R} 1$ & 1 & & 1.000 \\
\hline & 2 & 0.333 & 0.667 & & 2 & 0.091 & 0.909 \\
\hline & 3 & 0.429 & 0.571 & & 3 & & 1.000 \\
\hline \multirow[t]{3}{*}{ G-2 } & 1 & 0.414 & 0.586 & W1 & 1 & 0.414 & 0.586 \\
\hline & 2 & 0.242 & 0.758 & & 2 & 0.788 & 0.212 \\
\hline & 3 & 0.257 & 0.743 & & 3 & 0.500 & 0.500 \\
\hline \multirow[t]{3}{*}{ O-1 } & 1 & 0.655 & 0.345 & W2 & 1 & 0.483 & 0.517 \\
\hline & 2 & 0.576 & 0.424 & & 2 & 0.606 & 0.394 \\
\hline & 3 & 0.514 & 0.486 & & 3 & 0.857 & 0.143 \\
\hline \multirow[t]{3}{*}{$\mathrm{P} 1$} & 1 & 0.207 & 0.793 & $\mathrm{X} 1$ & 1 & 0.931 & 0.069 \\
\hline & 2 & 0.182 & 0.818 & & 2 & 0.697 & 0.303 \\
\hline & 3 & 0.257 & 0.743 & & 3 & 0.457 & 0.543 \\
\hline \multirow[t]{3}{*}{$\mathrm{T} 1$} & 1 & 0.345 & 0.655 & $\mathrm{X} 2$ & 1 & 0.966 & 0.034 \\
\hline & 2 & 0.303 & 0.697 & & 2 & 0.818 & 0.182 \\
\hline & 3 & 0.200 & 0.800 & & 3 & 0.457 & 0.543 \\
\hline Y2 & 1 & 0.621 & 0.379 & $\mathrm{~F} 1$ & 1 & 0.862 & 0.138 \\
\hline & 2 & 0.667 & 0.333 & & 2 & 0.970 & 0.030 \\
\hline & 3 & 0.743 & 0.257 & & 3 & 0.886 & 0.114 \\
\hline $\mathrm{B}^{\prime}$ & 1 & 0.138 & 0.862 & V1 & 1 & & 1.000 \\
\hline & 2 & 0.182 & 0.818 & & 2 & 0.121 & 0.879 \\
\hline & 3 & 0.200 & 0.800 & & 3 & 0.229 & 0.771 \\
\hline$D^{\prime}$ & 1 & 0.483 & 0.517 & $\mathrm{~V} 2$ & 1 & 0.241 & 0.759 \\
\hline & 2 & 0.394 & 0.606 & & 2 & 0.212 & 0.788 \\
\hline & 3 & 0.400 & 0.600 & & 3 & 0.286 & 0.714 \\
\hline E’2 & 1 & 0.724 & 0.276 & $\mathbf{J}$ & 1 & 0.586 & 0.414 \\
\hline & 2 & 0.576 & 0.424 & & 2 & 0.212 & 0.788 \\
\hline & 3 & 0.400 & 0.600 & & 3 & 0.057 & 0.943 \\
\hline E’3 & 1 & 0.517 & 0.483 & $\mathrm{~L}$ & 1 & 0.724 & 0.276 \\
\hline & 2 & 0.667 & 0.333 & & 2 & 0.667 & 0.333 \\
\hline & 3 & 0.371 & 0.629 & & 3 & 0.600 & 0.400 \\
\hline$E^{\prime} 4$ & 1 & 0.862 & 0.138 & M1 & 1 & & 1.000 \\
\hline & 2 & 0.818 & 0.182 & & 2 & 0.061 & 0.939 \\
\hline & 3 & 0.629 & 0.371 & & 3 & 0.500 & 0.500 \\
\hline $\mathrm{G}^{\prime}$ & 1 & 0.414 & 0.586 & M2 & 1 & & 1.000 \\
\hline & 2 & 0.576 & 0.424 & & 2 & 0.030 & 0.970 \\
\hline & 3 & 0.371 & 0.629 & & 3 & 0.057 & 0.943 \\
\hline I'1 & 1 & 0.310 & 0.690 & $S$ & 1 & 0.345 & 0.655 \\
\hline & 2 & 0.515 & 0.485 & & 2 & 0.576 & 0.424 \\
\hline & 3 & 0.429 & 0.571 & & 3 & 0.657 & 0.343 \\
\hline J'2 & 1 & 0.103 & 0.897 & U1 & 1 & 0.310 & 0.690 \\
\hline & 2 & 0.121 & 0.879 & & 2 & 0.152 & 0.848 \\
\hline & 3 & 0.257 & 0.743 & & 3 & 0.029 & 0.941 \\
\hline $\mathrm{K}^{\prime}$ & 1 & 0.069 & 0.931 & U2 & 1 & 0.448 & 0.552 \\
\hline & 2 & 0.061 & 0.939 & & 2 & 0.182 & 0.818 \\
\hline & 3 & 0.171 & 0.829 & & 3 & 0.057 & 0.943 \\
\hline $\mathrm{O}^{\prime}$ & 1 & 0.379 & 0.621 & U'1 & 1 & & 1.000 \\
\hline & 2 & 0.485 & 0.515 & & 2 & & 1.000 \\
\hline & 3 & 0.486 & 0.514 & & 3 & & 1.000 \\
\hline$Y^{\prime}$ & 1 & 0.207 & 0.793 & U'2 & 1 & 0.069 & 0.931 \\
\hline & 2 & 0.364 & 0.636 & & 2 & & 1.000 \\
\hline & 3 & 0.200 & 0.800 & & 3 & & 1.000 \\
\hline$Q^{\prime}$ & 1 & 0.586 & 0.414 & $\mathrm{H}^{\prime}$, & 1 & 0.310 & 0.690 \\
\hline & 2 & 0.545 & 0.455 & & 2 & & 1.000 \\
\hline & 3 & 0.143 & 0.857 & & 3 & 0.057 & 0.943 \\
\hline $\mathrm{B}^{\prime}$, & 1 & & 1.000 & $\mathrm{Z}$ & 1 & 0.724 & 0.276 \\
\hline & 2 & 0.121 & 0.879 & & 2 & 0.606 & 0.294 \\
\hline & 3 & 0.114 & 0.886 & & 3 & 0.743 & 0.257 \\
\hline
\end{tabular}

The South African Journal of Animal Science is available online at http://www.sasas.co.za/Sajas.html 
The mean sample size per locus, $\boldsymbol{P}, \boldsymbol{H}$ values and Nei's (1978) and Rogers' (1972) genetic distances are presented in Table 4. Only the Ptf-1 locus showed significant $(\mathrm{P}<0.05)$ deviation of allele classes from expected Hardy-Weinberg proportions in one of the breeds (Angone). This was due to a deficiency (-1.000) of heterozygotes. The degree of freedom for polymorphic loci was one in all cases where two alleles were observed, three for Alb (Angone and Bovine de Tete) and $\mathrm{Hb}$ (Bovine de Tete and Landim), $10 \mathrm{for}$ Alb and Tf (Angone and Bovine de Tete) and six for the Landim. Deficiencies of heterozygotes also occurred at the Hb locus for the Angone, at the Hb, Tf, Am and Ptf-2 loci for the Bovine de Tete and at the Hb, Tf, Ptf-2 and Am loci for the Landim. The individual heterozygosity $(\boldsymbol{h})$ values for the Angone ranged between 0 and 0.759 , between 0 and 0.594 for the Bovine de Tete and between 0 and 0.514 for the Landim.

Table 4 Sample size, average heterozygosity, percentage polymorphic loci (95\% criterion), Nei's (1978) genetic distance values above the diagonal and Rogers' (1972) genetic distance below the diagonal between three indigenous cattle breeds in Mozambique

\begin{tabular}{lccc}
\hline Breed & $\begin{array}{c}\text { Mean sample } \\
\text { size/locus }\end{array}$ & $\begin{array}{c}\text { Polymorphic loci } \\
(\%)\end{array}$ & $\begin{array}{c}\text { Heterozygosity } \\
H(\%)\end{array}$ \\
\hline Angone & 43 & 84 & 33 \\
Bovine de Tete & 33 & 88 & 33 \\
Landim & 35 & 90 & 35 \\
Genetic distance & Angone & Bovine de Tete & Landim \\
Angone & $* * *$ & & \\
Bovine de Tete & 0.134 & 0.028 & 0.064 \\
Landim & 0.187 & $* * *$ & 0.028 \\
\hline
\end{tabular}

Population differences were studied by calculating fixation indices for each locus as well as the mean weighted value across all loci. The mean pairwise $\mathbf{F}_{\text {is }}$ values across all loci were 0.840, 0.843 and 0.857 for Angone and Landim, Angone and Bovine de Tete, and Bovine de Tete and Landim respectively. The $\mathbf{F}_{\mathbf{i t}}$ values were 0.851 , 0.849 and 0.862 , and the $\mathbf{F}_{\text {st }}$ values were $0.069,0.035$ and 0.038 respectively for the above-mentioned pairs. Pairwise comparisons of contingency Chi-square analysis at all loci indicated significant $(\mathrm{P}<0.05)$ differences at 19 (Angone and Bovine de Tete) and 20 (the other two breeds) loci and the totals between all breed pairs studied. Significant differences between all three breeds were obtained at six blood factor loci (X1, X2, J, U1, U2 and H") and at Tf (between Bovin de Tete and Landim), Hb, Alb, Tf and Ptf-2 (between Angone and Landim) and Ptf-2 (Between Angone and Bovine de Tete). Nei's (1978) genetic distances between the three breeds ranged from 0.028 to 0.064 (Table 4); it was least between Bovine de Tete and Landim, followed by Angone and Bovine de Tete, and largest between Angone and Landim for the other three distance measures. The phenograms produced using all of the above-mentioned genetic distance estimates group the Bovine de Tete with the Angone, and this group is separated from the Landim.

The three breeds all showed close similarity in genetic variability with a mean number of alleles per locus of 2.0. The deviation of allele classes from expected Hardy-Weinberg proportions at the Pff- 1 locus in the Angone population can be attributed to heterozygote deficiency due to some sort of natural selection. The estimate of $\boldsymbol{H}$ for the three breeds ranged from 33 to $35 \%$, indicating very high genetic variation in all breeds. These values compare well with the results obtained in a study of indigenous cattle breeds in South Africa (Kotze \& Muller, 1994). The indigenous breeds have a higher genetic variation than the exotic breeds.

Genetic distances were calculated between the three morphologically different breeds to determine whether the breeds are genetically different. The origin of the breeds is, however, still under dispute. The smallest genetic distance was between the Angone and Bovine de Tete breeds and the biggest was between the Landim and Angone breeds. The phenogram constructed from the distances clearly illustrated the relatedness of the Bovine de Tete with the Angone, while the Landim formed a separate cluster. It was concluded that the Bovine de Tete and the Angone have more genes in common and that a possible admixture of genes took place some time during history. 
Some major factors contributing to genetic similarity are adaptation to hot climates and tick and disease resistance. One of the major factors contributing to genetic differences between breeds or populations is the degree of geneflow rather than isolation mechanisms in subdivided populations. The population structure, as determined with hierarchical $\boldsymbol{F}$-statistics, gives the total inbreeding coefficient estimate $\left(\mathbf{F}_{\text {it }}\right)$ as $0.849-0.862($ mean $=0.854)$ for the indigenous breed pairs studied. The inbreeding in the individuals relative to the total population is quite large and could be due to genetic drift among the populations studied. Values of $\mathbf{F}_{\text {is }}$ in most natural populations are close to zero. In this study, $\mathbf{F}_{\text {is }}(0.840-0.857$; mean $=0.847)$ is close to one, which indicates little admixture between the breeds, and the low $\mathbf{F}_{\text {st }}$ value (mean $=0.047$ ) shows that there is little genetic differentiation between the three breeds. This is in agreement with the small genetic distance value $($ mean $=0.04)$. The mean genetic distance between conspecific populations is 0.05 (Shaklee et al., 1982). On-going programmes of breed structure analysis could ensure that the maximum genetic variability is maintained in each indigenous breed. This is particularly useful for selection of donors for semen and embryos, and in the preparation of group breeding programmes. Crossbreeding programmes using superior indigenous breeds as dams and exotic B. taurus and B. indicus as terminal sire breeds were recommended where controlled mating is feasible (Hetzel, 1988).

\section{Conclusions}

This study has shown that the three indigenous breeds of Mozambique appear to be genetically closely related, but has also shown that specific differences (as indicated by the many loci where significant differences between breeds were found) do occur between the three breeds. The Bovine de Tete breed can be regarded as a separate breed, but is intermediate to Angone and Landim.

\section{Acknowledgements}

This study was conducted at the Eduardo Montlana University in Maputo, Mozambique and was financially supported by the GTZ programme. Our sincere thanks to personnel of the ARC blood typing laboratory, H.M. Bekker, R. Wolmarans and S.J. du Plessis for technical assistance and to S. Maciel and L. Tawah for assisting with the sampling of the animals.

\section{References}

Alberro, M., 1983. The indigenous cattle of Mozambique. World Animal Review 48, 12-17.

Augusto, L., Weitze, K.F., Otto, F., Maciel, S. and Tomo, P., 1997. Onset and duration of oestrus related to the time of ovulation and fertility in a herd of Nguni cattle in South Mozambique. Reprod. Dom. Anim. 32, 303-307.

Cavalli-Sforza, L.L. and Edwards, A.W.F., 1967. Phylogenetic analysis: models and estimation procedures. Evolution 21, 550-570.

Hetzel, D.J.S., 1988. Comparative productivity of the Brahman and some indigenous Sanga and Bos indicus breeds of East and Southern Africa. Anim. Breeding Abstr. 4, vol. 56.

Kotze, A. and Muller, G.H., 1994. Genetic relationships between southern African cattle breeds. Proc. $3^{\text {rd }}$ World Congr. Genet. Appl. Livestock Prod., Guelph, Canada, 20, 201.

Maillard, J.C., Kemp, S.J., Naves, M., Palin, C., Demangel, C., Accipe, A., Maillard, N. and Bensaid, A. 1993. An attempt to correlate cattle breed origins and diseases associated with or transmitted by the tick Amblyomma variegatum in the French West Indies.1993. Revue Elev. Med. Vet. Pays. trop. 46(1-2), 283290.

Manwell, C. and Baker, C.M.A., 1980. Chemical classification of cattle. 2. Phylogenetic tree and specific status of the Zebu. Anim. Blood Grps. Biochem. Genet. 11,151-162.

Mason, I.L., 1975. Factors influencing the world distribution of cattle. In: Beef cattle production in developing countries. Ed. A.J. Smith, Edinburgh University Press, 29-42.

Nei, M., 1972. Genetic distance between populations. Am. Nat. 106, 283-292.

Nei, M., 1978. Estimation of average heterozygosity and genetic distance from a small number of individuals. Genetics 89, 583.

Rogers, J.S., 1972. Measures of genetic similarity and genetic distance. Studies in Genetics, Univ. Texas Publ. $7213,145-153$.

Shaklee, J.B.,Tamary, C.S. and Waples, R.S., 1982. Speciation and evolution of marine fishes studied by the electrophoretic analysis of proteins. Pac. Sci. 36, 141-157.

Stormont, C., 1962. Current status of blood groups in cattle. Ann. N.Y. Acad. Sci. 97, 251-268.

Swofford, D.L. and Selander, R.B., 1981. BIOSYS-1. A FORTRAN program for the comprehensive analysis of electrophoretic data in population genetics and systematics. J. Heredity 72, 281. 